\title{
Ability of prostate specific antigen to predict bone scan result in prostate cancer patients
}

\author{
Taufan Tenggara, Rainy Umbas
}

\begin{abstract}
Abstrak
Tujuan penelitian ini adalah untuk melihat hubungan antara serum Prostate Specific Antigen ( PSA ), stadium klinis lokal, grading tumor dengan hasil bone scan dalam usaha mengevaluasi kemampuan serum PSA untuk memprediksi hasil bone scan pada penderita baru kanker prostat. Suatu penelitian retrospektif dilaksanakan terhadap data penderita kanker prostat yang didiagnosis di institusi penulis antara Januari 1995 hingga Desember 2003. Subyek penelitian ditolak apabila nilai PSA diperoleh setelah dilakukan manipulasi uretra atau sesudah penderita mendapatkan terapi. Hubungan antara hasil bone scan dengan serum PSA, stadium klinis lokal dan grading tumor dianalisis. Hasil penelitian menunjukkan dari 103 penderita yang termasuk dalam penelitian ini, 61 penderita (59,2\%) mempunyai hasil bone scan positif dengan rerata nilai PSA 471,13 $\pm 853,34 \mathrm{ng} / \mathrm{ml}$, sedangkan 42 penderita $(40,8 \%)$ mempunyai hasil bone scan negatif dengan rerata nilai PSA 61,00 $\pm 124,47 \mathrm{ng} / \mathrm{ml}(\mathrm{p}<0,05)$. Resiko untuk mendapatkan hasil bone scan positif bertambah besar dengan meningkatnya nilai PSA, stadium klinis lokal dan grading tumor ( $p<0,05)$. Dengan menggunakan kurva Receiver Operating Characteristic ( ROC), terbukti bahwa PSA mempunyai korelasi terbaik dengan hasil bone scan ( Area Under Curve =0,812 ). Kombinasi serum PSA, stadium klinis lokal dan grading tumor mempunyai kemampuan terbaik dalam memprediksi hasil bone scan. Dari 19 penderita dengan serum PSA $<10 \mathrm{ng} / \mathrm{ml}$, terdapat 5 penderita yang mempunyai hasil bone scan positif; sedangkan dari 8 penderita dengan serum PSA $<10 \mathrm{ng} / \mathrm{ml}$, stadium klinis T1 atau T2 dan grading tumor derajat 1 atau 2, tidak satupun menunjukkan metastasis tulang. Dari penelitian ini dapat disimpulkan bahwa pemeriksaan rutin bone scan tidak diperlukan bagi penderita baru kanker prostat dengan serum PSA $<10 \mathrm{ng} / \mathrm{ml}$, stadium klinis T1 atau 2 dan grading tumor 1 atau 2. (Med J Indones 2004; 13: 151-5)
\end{abstract}

\begin{abstract}
The objective of this study is to assess the relation between serum Prostate Specific Antigen ( PSA ), clinical tumor stage, tumor grade and bone scan result in an attempt to seek the ability of serum PSA to predict bone metastases in newly diagnosed prostate cancer patients. A retrospective analysis was conducted on clinical files of prostate cancer patients which were diagnosed in our institutions between January 1995 and December 2003. Patients on which initial serum PSA were obtained after urethral manipulation or after receiving therapy were excluded. The results of bone scans were related to levels of serum PSA, clinical tumor stage and tumor grade. Of 103 patients who were included in this investigation, 61 patients ( 59.2\%) had a positive bone scan and 42 patients ( $40.8 \%$ ) had a negative bone scan with mean PSA value $471.13 \pm 853.34 \mathrm{ng} / \mathrm{ml}$ and $61.00 \pm 124.47 \mathrm{ng} / \mathrm{ml}$ respectively $(p<0.05)$. The risk of having a positive bone scan increased with advancing serum PSA levels, clinical tumor stage and tumor grade ( $p<0.05)$. Using Receiver Operating Characteristic curves, PSA had the best correlation with bone scan results ( the area under curve was 0.812 ). Bone scan results were predicted best by the combination of serum PSA, clinical tumor stage and tumor grade. Bone scans were positive in 5 of 19 patients with PSA level $<10 \mathrm{ng} / \mathrm{ml}$. None of 8 patients with PSA levels $<10 \mathrm{ng} / \mathrm{ml}$, clinical tumor stage T1 or 2 and tumor grade 1 or 2 had a positive bone scan. In conclusion, we suggest that routine bone scan examination may not be necessary in patients with newly diagnosed, untreated prostate cancer, who have serum PSA level $<10 \mathrm{ng} / \mathrm{ml}$ with clinical tumor stage T1 or 2 and tumor grade 1 or 2 (Med J Indones 2004; 13: 151-5).
\end{abstract}

Keywords: prostate cancer, bone metastases, tumor grade, tumor stage

Division of Urology, Department of Surgery, Faculty of Medicine, University of Indonesia/Dr. Cipto Mangunkusumo Hospital, Jakarta, Indonesia
Prostate cancer is now the most common cancer and the second leading cause of death from cancer among men in the USA and Europe. ${ }^{1}$ 
With the ageing of the population, the public health burden of prostate cancer will certainly increase in the future. ${ }^{1}$ Diagnostic and therapeutic protocols are certainly needed in managing patient to reduce costs and preserve quality. ${ }^{2}$

Until recently, the standard staging evaluation for a patient with newly diagnosed, biopsy-proved prostate cancer included digital rectal examination, serum Prostate Specific Antigen ( PSA ) determination and bone scan examination. ${ }^{3}$ The primary objective of clinical staging of prostate cancer is to ensure that the patient will receive the most appropriate treatment modality. ${ }^{1}$

Chybowsky et al suggested that serum PSA has been shown to correlate directly with clinical stage. On the other hand, clinical tumor stage, tumor grade and serum PSA correlated positively with bone scan findings. ${ }^{4}$ Several investigators concluded that a low serum PSA concentration rarely had skeletal metastases, so that a routine bone scan in a previously untreated prostate cancer patients with a low serum PSA concentration $(<10 \mathrm{ng} / \mathrm{ml})$ might not be necessary. ${ }^{1,3,4,5}$

At the Division of Urology, Cipto Mangunkusumo Hospital and Dharmais National Cancer Center Jakarta, bone scan is still routinely performed to all newly diagnosed prostate cancer.

The objective of this study is to assess the relation between serum PSA, clinical tumor stage, tumor grade and bone scan result in an attempt to seek the ability of serum PSA to predict bone metastases in newly diagnosed prostate cancer patients.

\section{METHODS}

We conducted a retrospective analysis on clinical files from prostate cancer patients which were diagnosed at the Division of Urology, Cipto Mangunkusumo Hospital and Dharmais National Cancer Center Jakarta between January 1995 and December 2003. Patients on which initial serum PSA were obtained after urethral manipulation (catheterization, Transurethral Resection of the Prostate / TUR-P) or after receiving therapy (either surgery, radiation or hormonal) were excluded.

Clinical data on tumor stage, grade, serum PSA and bone scan results were obtained from the medical records. Clinical tumor stage was categorized according to the TNM staging system (American Joint Committee on Cancer, 2002). ${ }^{6}$ Histological grades were determined as either G1 (well differentiated), G2 (moderately differentiated) or G3-4 (poorly differentiated / undifferentiated) according to WHO classification. $^{7}$

All bone scans were performed using ${ }^{99 \mathrm{~m}}$ Technetium $\left({ }^{99 \mathrm{~m}} \mathrm{Tc}\right)$ - methylene diphosphonate and interpreted as either positive or negative.

The serum PSA distribution for the bone scan groups was compared using the Mann-Whitney $U$ test. The relation between serum PSA, clinical tumor stage, tumor grade and bone scan results were analyzed using Chi Square test, with $\mathrm{p}<0.05$ considered to indicate statistical significance. Logistic regression analysis with the likelihood ratio Chi Square test was also used to define the correlation between each variable ( serum PSA, clinical tumor stage and tumor grade ) and bone scan results. This technique was used to test univariate variables as well as multivariate combinations of variables to determine the best model for prediction of bone metastases. Finally, Receiver Operating Characteristic (ROC) curves were determined to evaluate the efficiency of PSA, clinical tumor stage and tumor grade for the diagnosis of bone metastases.

\section{RESULTS}

Between January 1995 and December 2003, 286 histopathological-proved prostate cancer patients were registered in our institutions. We excluded 183 patients from the study because their serum PSA were obtained after urethral manipulation or after receiving therapy. Of 103 patients who were included in this investigation, the mean age was $68.13 \pm 9.22$ years ( range 40 to 92 years ). Serum PSA ranged from $0.20-4663.00 \mathrm{ng} / \mathrm{ml}$ ( median $52.10 \mathrm{ng} / \mathrm{ml}$ ).

Of 103 patients who were included in this study, 61 patients $(59.2 \%)$ had a positive bone scan and 42 patients ( $40.8 \%$ ) had a negative bone scan with mean PSA value $471.13 \pm 853.34 \mathrm{ng} / \mathrm{ml}$ and $61.00 \pm 124.47$ $\mathrm{ng} / \mathrm{ml}$ respectively $(\mathrm{p}=0.000)$ ( Figure 1 ).

Using Chi Square test, the relation between serum PSA, clinical tumor stage, tumor grade and bone scan results were significantly different $(\mathrm{p}<0.05)$ ( Table 2 ). 
Table 1. Characteristic of patients' population based on serum PSA level, clinical tumor stage and tumor grade $(\mathrm{n}=$ 103 ).

\begin{tabular}{ccr}
\hline Variable & No. of patients & $(\%)$ \\
\hline Serum PSA ( ng/ml ) & & \\
$<10$ & 18 & 17.5 \\
$10-20$ & 10 & 9.7 \\
$20.1-50$ & 20 & 19.4 \\
$>$ 50 & 55 & 53.4 \\
Clinical Tumor Stage ( T ) & & \\
T1 & 23 & 22.3 \\
T2 & 27 & 26.2 \\
T3 & 23 & 22.3 \\
T4 & 30 & 29.1 \\
Tumor Grade ( G ) & & \\
G1 & 8 & 7.8 \\
G2 & 26 & 25.2 \\
G3-4 & 69 & 67.0 \\
\hline
\end{tabular}

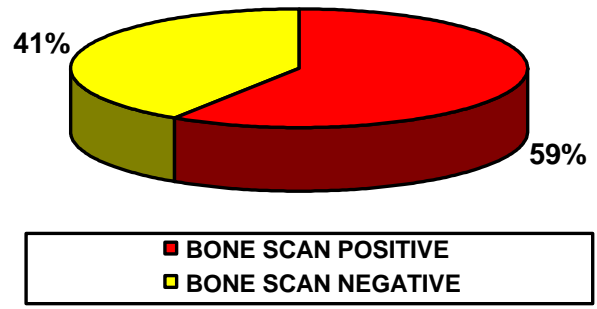

Figure 1. Distribution of patients by bone scans results

Table 2. Correlation of serum PSA level, clinical stage and tumor grade with bone scan result $(\mathrm{n}=103)$.

\begin{tabular}{|c|c|c|c|c|c|c|}
\hline \multirow{2}{*}{\multicolumn{2}{|c|}{ Variable }} & \multicolumn{4}{|c|}{ Bone scan } & \multirow{2}{*}{$\mathrm{p}$} \\
\hline & & \multicolumn{3}{|c|}{ Positive } & \multirow{2}{*}{$\frac{\text { Negative }}{(13.6 \%)}$} & \\
\hline & $\mathrm{A}:<10 \mathrm{ng} / \mathrm{ml}$ & 5 & $(4.9 \%)$ & 14 & & \\
\hline & $: \geq 10 \mathrm{ng} / \mathrm{ml}$ & 56 & $(54.4 \%)$ & 28 & $(27.2 \%)$ & 0.001 \\
\hline \multirow[t]{2}{*}{$\mathrm{T}$} & : T1-T2 & 22 & $(21.4 \%)$ & 28 & $(27.2 \%)$ & \\
\hline & : T3-T4 & 39 & $(37.9 \%)$ & 14 & $(13.6 \%)$ & 0.002 \\
\hline \multirow[t]{2}{*}{ G } & : G1-G2 & 13 & $(12.6 \%)$ & 21 & $(20.4 \%)$ & \\
\hline & : G3-G4 & 48 & $(46.6 \%)$ & 21 & $(20.4 \%)$ & 0.002 \\
\hline
\end{tabular}

Table 3. Univariate predictors of bone scan results by logistic regression analysis with the likelihood ratio chi square test.

\begin{tabular}{lcc}
\hline \multirow{2}{*}{ Variable } & \multicolumn{2}{c}{ Bone scan results } \\
\cline { 2 - 3 } & Chi Square & p value \\
\hline Serum PSA & 22.3 & 0.000 \\
Clinical Tumor Stage ( T ) & 21.8 & 0.000 \\
Tumor Grade ( G ) & 10.0 & 0.007 \\
\hline
\end{tabular}

Table 3 summarizes the univariate variables as predictors of the bone scan results. Using the Chi Square test, serum PSA was the best single predictor of bone scan findings, followed by tumor stage and tumor grade with $\mathrm{p}$ values of $0.000,0.000$ and 0.007 , respectively.

Multivariate logistic regression analysis was also used to determine if combining any of the other 2 clinical parameters (tumor stage or tumor grade) with PSA could increase the ability of PSA to predict bone scan findings.

Table 4. Multivariate predictors of bone scan results by logistic regression analysis with the likelihood ratio chi square test.

\begin{tabular}{|c|c|c|}
\hline \multirow{2}{*}{ Variables } & \multicolumn{2}{|c|}{ Bone scan results } \\
\hline & Chi Square & $\mathrm{p}$ value \\
\hline $\begin{array}{l}\text { - Clinical Tumor Stage ( } \mathrm{T} \text { ) and } \\
\text { Tumor Grade ( G ) }\end{array}$ & 24.6 & 0.000 \\
\hline $\begin{array}{l}\text { - Serum PSA and } \\
\text { Tumor Grade ( G ) }\end{array}$ & 28.5 & 0.000 \\
\hline $\begin{array}{l}\text { - Serum PSA and } \\
\text { Clinical Tumor Stage ( } \mathrm{T} \text { ) }\end{array}$ & 33.8 & 0.000 \\
\hline $\begin{array}{l}\text { - Serum PSA, Clinical Tumor Stage } \\
\text { ( T ) and Tumor Grade ( } \mathrm{G} \text { ) }\end{array}$ & 36.1 & 0.000 \\
\hline
\end{tabular}

All combinations predicted bone scan results better than any single variable alone. Bone scan results were predicted best by the combination of serum PSA, clinical tumor stage and tumor grade ( Table 4 ).

Table 5. Negative Predictive Value of parameters in determining bone metastases

\begin{tabular}{lc}
\hline Parameter & Negative Predictive Value \\
\hline - PSA $<10 \mathrm{ng} / \mathrm{ml}$ & $73.68 \%$ \\
- PSA $<20 \mathrm{ng} / \mathrm{ml}$ & $78.57 \%$ \\
- PSA $<50 \mathrm{ng} / \mathrm{ml}$ & $65.96 \%$ \\
- Clinical tumor stage T1 or 2 & $56.00 \%$ \\
- Tumor grade 1 or 2 & $61.76 \%$ \\
- PSA $<10 \mathrm{ng} / \mathrm{ml}$ with clinical tumor & $100.00 \%$ \\
$\quad$ stage T1 or 2 and tumor grade 1 or 2 \\
\hline
\end{tabular}




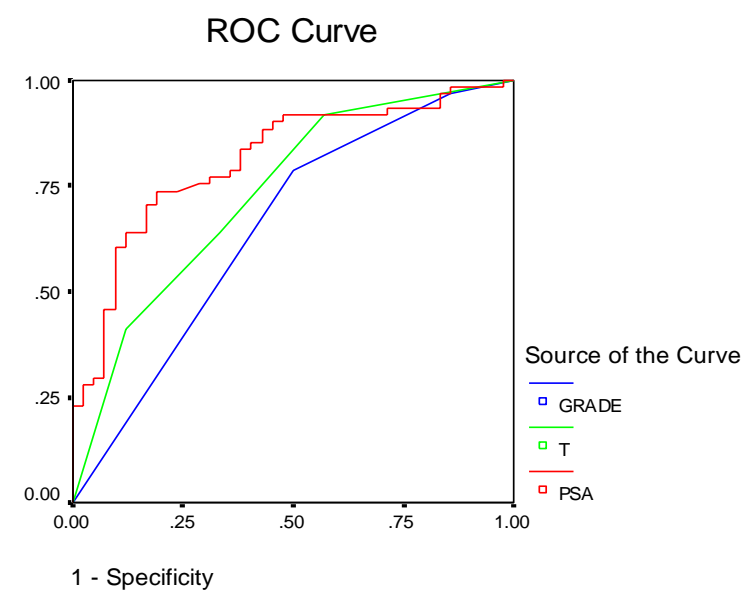

Figure 2. Receiver Operating Characteristic curve for detecting positive bone scans in 103 newly diagnosed prostate cancer patients. Sensitivity and specificity are plotted for different cutoff points of serum PSA, clinical tumor stage and tumor grade

\section{DISCUSSION}

Since its discovery by Wang et al in 1979, PSA has become the most important tumor marker for prostate cancer. Although produced by all types (normal, hyperplastic and cancerous) of prostatic tissue, PSA has been shown to correlate directly with clinical stage. ${ }^{4,8}$ PSA concentration increases with advancing clinical stage and is proportional to the estimated tumor volume. ${ }^{9,10}$

The most important prognostic indicator at initial diagnosis is the presence or absence of bone metastases. ${ }^{11}$ The most sensitive technique for detecting bone metastases is bone scan, ${ }_{1,4,11,12}$ which was developed in 1963 and has false negative scans less than $1 \% .{ }^{4}$ It is superior to clinical evaluation and bone radiographs, as well as measurement of serum Alkaline Phosphatase (ALP) and Prostatic Acid Phosphatase (PAP) level. ${ }^{4,13}$ Based on these reasons, bone scan is performed routinely in determining clinical stage for all newly diagnosed prostate cancer. ${ }^{11,12}$

Although extremely accurate in evaluating the skeleton for metastases disease, the radionuclide bone scan is a costly diagnostic study. ${ }^{4}$ More over, at initial presentation, only approximately $20-25 \%$ of men with prostate cancer have bone metastases. ${ }^{12}$ Because serum PSA levels are proportional to tumor volume and clinical stage, minimal elevations in serum PSA in newly diagnosed patients with prostate cancer may identify a subgroup of patients with a negligible risk for positive bone scans. ${ }^{1,9}$

This study revealed that bone scan-positive patients had a statistically higher level of PSA than the bone scan-negative patients $(\mathrm{p}<0.05)$ and the risk of having a positive bone scan increased with advancing serum PSA level, clinical tumor stage and grade $(\mathrm{p}<$ 0.05 respectively).

Chybowsky et $\mathrm{al}^{4}{ }^{4}$ who conducted a retrospective study in Mayo Clinic, involving 521 newly diagnosed, untreated prostate cancer patients; concluded that serum PSA, clinical tumor stage and grade correlated positively with the incidence of a positive bone scan. Gleave et $\mathrm{al}^{9}$ from Vancouver Hospital and Health Sciences Center reported that the risk of having a positive bone scan increased with increasing serum PSA levels and advancing tumor stage and grade. Other investigators such as Lorete et $\mathrm{al}^{14}$ and Morote et $\mathrm{al}^{15}$ recommended that Bone Alkaline Phosphatase (BAP) could be a complementary marker to PSA in the diagnosis of bone metastases in patients with prostate cancer.

Oesterling et al has successfully proved that serum PSA is the most accurate and reliable predictor of the bone scan findings. ${ }^{3}$ That matter has also been proved in this study. PSA was the best single predictor bone scan results, followed by tumor stage and tumor grade (Table 3). ROC curves also revealed that serum PSA has Area Under Curve $($ AUC $)=0.812$, higher than either clinical tumor stage ( 0.733 ) or grade $(0.650)$ (Figure 2).

In our study, the combinations of serum PSA, clinical tumor stage and tumor grade more accurately predicted bone scan results than any single variable, with the combination of all 3 variables providing the most statistically significant prediction (Table 4). This condition was analogous to the 'Partin Tables' which using the combination of serum PSA, clinical stage and Gleason score to predict final pathological stage in prostate cancer patients. ${ }^{16,17}$ However, Gleason grading of the prostate biopsy alone remains a poor predictor of pathological outcome. ${ }^{18}$

Although serum PSA is the best predictor in determining bone scan result, serum PSA alone at different cutoff points $(<10 \mathrm{ng} / \mathrm{ml},<20 \mathrm{ng} / \mathrm{ml}$ and $<50 \mathrm{ng} / \mathrm{ml}$ respectively ) have low negative predictive value $(65 \%-78 \%)$. On the other hand, if serum PSA is combined with clinical tumor stage $(\mathrm{T})$ and grade $(\mathrm{G})$, 
it will have the best ability to predict a negative bone scan finding (Table 5). This study revealed that bone scans were positive in 5 of 19 patients with PSA level $<10 \mathrm{ng} / \mathrm{ml}$. None of 8 patients with PSA level $<10$ $\mathrm{ng} / \mathrm{ml}$, clinical tumor stage $\mathrm{T} 1$ or 2 and tumor grade 1 or 2 had a positive bone scan (negative predictive value $100 \%$ ).

Several studies reported that routine bone scan examination was not necessary in patients with newly diagnosed, untreated prostate cancer who had a low serum PSA $(<10 \mathrm{ng} / \mathrm{ml}) .^{1,3,4,19,20}$ Kosuda et al, in a multicenter retrospective study in Japan, suggested that baseline bone scans could be eliminated in patients with newly diagnosed prostate cancer who had serum PSA level $\leq 10 \mathrm{ng} / \mathrm{ml}$ or Gleason grade $\leq 2 .{ }^{5}$ Gleave et al also concluded that bone scans were indicated when PSA levels were above $10 \mathrm{ng} / \mathrm{ml}$, or with T3 or poorly differentiated disease. ${ }^{9}$

\section{CONCLUSION}

PSA level, clinical tumor stage and grade correlates with bone scan results in newly diagnosed prostate cancer patients. The risk of having a positive bone scan increases with advancing serum PSA level, clinical tumor stage and grade. Bone scan result is predicted best by the combination of serum PSA, clinical tumor stage and tumor grade.

There is no bone metastases lesion detected from bone scan results of newly diagnosed prostate cancer patients at our institutions with serum PSA level $<10$ $\mathrm{ng} / \mathrm{ml}, \mathrm{T} 1$ or 2 and grade 1 or 2 , so that routine bone scan examination may not be necessary as a part of determining clinical stage in this group of patients.

\section{REFERENCES}

1. Wymenga LFA, Boomsma JHB, Groenier K, Piers DA, Mensink HJA. Routine bone scans in patients with prostate cancer related to serum prostate-specific antigen and alkaline phosphatase. BJU Int 2001; 88:226-30.

2. Murtagh D, Baum N. Implementing guidelines and protocols to reduce costs and preserve quality. Infect Urol 1998; 11(3):69-73.

3. Oesterling JE. Using PSA to eliminate the staging radionuclide bone scan. Significant economic implications. Urol Clin North Am 1993; 20:705-11.

4. Chybowski FM, Keller JJL, Bergstralh EJ, Oesterling JE. Predicting radionuclide bone scan findings in patients with newly diagnosed, untreated prostate cancer: prostate specific antigen is superior to all other clinical parameters. J Urol 1991; 145:313-8.

5. Kosuda S, Yoshimura I, Aizawa T, Koizumi K, Akakura $\mathrm{K}$, Kuyama $\mathrm{J}$, et al. Can initial prostate specific antigen determinations eliminate the need for bone scans in patients with newly diagnosed prostate carcinoma ? Cancer 2002 ;94(4):964-72.

6. Greene FL, Page Dl, Fleming ID, Fritz AG, Balch CM, Haller DG, et al, editors. AJCC Cancer staging manual. $6^{\text {th }}$ ed. New York: Springer; 2002.

7. Mostofi FK, Sesterhenn I, Sobin LH. Histological typing of prostate tumours. In: International histological classification of tumours. No. 22. Geneva:WHO;1980.

8. Oesterling JE. Prostate specific antigen: a critical assessment of the most useful tumor marker for adenocarcinoma of the prostate. J Urol 1991; 145:907-23.

9. Gleave ME, Coupland D, Drachenberg D, Cohen L, Kwong S, Goldenberg L, et al. Abilitiy of serum prostatespecific antigen levels to predict normal bone scans in patients with newly diagnosed prostate cancer. Urology 1996; 47:708-12.

10. Freitas JE, Gilvydas R, Ferry JD, Gonzales JA. The clinical utility of prostate-specific antigen and bone scintigraphy in prostate cancer follow-up. J Nucl Med 1991; 32:1387-90.

11. Sissons GRJ, Clements R, Peeling WB, Penney MD. Can serum prostate-specific antigen replace bone scintigraphy in the follow-up of metastatic prostatic cancer ? $\mathrm{Br} \mathbf{J}$ Radiol 1992; 65:861-4.

12. Gerber G, Chodak GW. Assessment of value of routine bone scans in patients with newly diagnosed prostate cancer. Urology 1991; 37:418-22.

13. Lee CT, Oesterling JE. Cancer of the prostate: diagnosis and staging. In: Oesterling JE, Richie JP, editors. Urologic Oncology. Philadelphia: WB Saunders; 1997.p.357-77.

14. Lorente JA, Morote J, Raventos C, Encabo G, Valenzuela $\mathrm{H}$. Clinical efficacy of bone alkaline phosphatase and prostate specific antigen in the diagnosis of bone metastasis in prostate cancer. J Urol 1996 ;155:1348-51.

15. Morote J, Lorente JA, Encabo G. Prostate carcinoma staging : clinical utility of bone alkaline phosphatase in addition to prostate specific antigen. Cancer 1996; 78(11):2374-8.

16. Partin AW, Yoo J, Carter HB, Pearson JD, Chan DW, Epstein JI, et al. The use of prostate specific antigen, clinical stage and gleason score to predict pathological stage in men with localized prostate cancer. J Urol 1993; 150:110-4.

17. Partin AW, Mangold LA, Lamm DM, Walsh PC, Eipstein JI, Pearson JD. Contemporary update of prostate cancer staging nomograms (Partin Tables) for the new millennium. Urology 2001; 58(6):843-8.

18. Lattouf JB, Saad F. Gleason score on biopsy : is it reliable for predicting the final grade on pathology? BJU Int 2002; 90:694-9.

19. Kirby RS, Brawer MK, Denis LJ. Prostate Cancer. $3^{\text {rd }}$ ed. Oxford: Health Press; 2001.p.30-2.

20. Colberg JW. Locally advanced and late prostate cancer. In: Weiss RM, George NJR, O'Reilly PH, editors. Comprehensive Urology. London: Mosby; 2001.p.409-24. 
